\title{
Ataxia-telangiectasia 老伴う免疫不全症の長期予後
}

\section{第 3 編 免疫異常の進行性について}

\author{
松岡道子・松 岡宏・岡田純一 \\ 水野 周久・宇理須 厚 雄・佐藤 千寿子 \\ 柘植 郁哉・鳥居 新平
}

Follow-up studies of immunological disorders in patients with ataxia-telangiectasia

III. Progressive disorders in cellular and humoral immunity

\author{
Michiko Matsuoka, Hiroshi Matsuoka, Junichi Okada, Tomohisa Mizuno, \\ Atsuo Urisu, Chizuko Sato, Ikuya Tsuge and Shimpei Torii
}

Department of Pediatrics, Nagoya University School of Medicine

\section{【Summary】}

We were able to evaluate immunological function of 6 patients with ataxia-telangiectasia (AT) and follow up for long periods. Six cases were diagnosed and studied between 2 to 10 years of age for the first time. At the time of report, 10 to 20 years of age, 4 patients are alive.

1) A 7-year-old female had severe defect in both humoral and cellular immunity and died following serious sinopulmonary tract infection at age 10.

2) Her 2-year-old male sib, who had mild cellular immune deficiency, developed $\mathrm{T}$ cell ALL at age 10. One month before the time when the ALL blasts had appeared in his peripheral blood flow, his cellular immune deficiency was more remarkable.

3) Ten and 9 years old female sib had no immunological abnormality at the time of diagnosis. However, elder sister died at 20 years old following a intractable pneumonia for period of 18 months. And evaluation of her immune function at 19 years old showed marked cellular immune deficiency and almost normal humoral immunity.

4) Eleven and 7 years old male sib showed $\operatorname{IgA}$ and $\operatorname{IgE}$ defect without cellular immune deficiency. Elder brother had recurrent pulmonary infection and showed bronchiectasia on chest X-ray.

5) Three out of 6 cases alive at the time of this report without malignancy, who are 20, 19 and 16 years of age, had no obvious deficiency of cellular immunity early in the course. However, as they grew older, recurrent infection appeared and cerebellar ataxia progressed, and deficiencies of cellular immunity became more remarkable. 
The immunological defects in AT were reported to vary from patient to patient, and in each patient with respect to age. Our present data showed the heterogeneity of AT in view of immunodeficiency. The critical period when the serious defects in cellular immunity occur vary from patient to patient, i.e., some have immune defect at early age, the other have late at adolescent age.

Serious defects in cellular immunity in AT is closely related to susceptibility to lethally pulmonary infection and occurrence of lymphoreticular malignancies. Therefore, precise immunological follow up studies of this disease are needed. In vitro lymphocyte DNA synthesis stimulated with PHA and/or PWM was found to be reliable method monitoring the defect in cellular immunity.

Key words: ataxia-telangiectasia, $\operatorname{IgA}, \mathrm{E}$ deficiency, T-B cell co-culture, progressive immune deficiency

\section{【概 要】}

典型的な Ataxia-telangiectasia の自験 6 例について, 咟床免疫学的に長期予後を検討した.

(1) 6 例の免疫能は症例ごとに異なっていたが，どの例も進行性に低下した.

(2) 進行の度合も症例ごとに異なるが，いずれも10 歳代後半には紐胞性免疫能の低下をきたした。

(3) 幼小児期の一時点の免疫能から生命予後は予測できず，経時的な観察が必要である.

(4) 感染死や悪性腫瘍化と関連染いのは，細胞性免疫能の低下であり，その低下の指標として PHA，PWM による リンパ球 DNA 合成能検查が有力である.

\section{I.はじめに}

Ataxia-telangiectasia（以下 AT) は進行性の小脳性 失調症や反復呼吸器感染, 覀性腫瘍の合併のため若年で 死亡する例が多く，免疫不全症としても特異である゙1).

我々は先に感染症で死亡した 2 例2) と, T cell ALL を 発症した 1 例了) を報告した。 そこで得られた知見は，免 疫不全状態は 3 例とも異なり, 幼小児期のある一時点で とらえた免疫能から予後は判定できず，経時的にみると 症例ごとに速度に差はあるるのの加齢に伴い悪化すると いうことであった．免疫不全は AT の多彩な症状のう ちの1つであるが，生命予後を左右する大きな因子であ り，検查上どの免疫学的指標が患児の感染死，腫煌化に 至る予後の判定に重要かを探ることが必要であることを 痛感した. しかし文献的には長期にわたって追跡し, こ の点に言及した報告は極めて少ない，そこで今回，別の 3 例の AT について経時的に追跡し, 免疫不全の進行性 についていくつかの指標から探ってみた。 また，既報の 3 例とも併せて比較し，AT の免疫不全と予後の関連に

ついて述べたい.

II. 症例

1. 症例紹介

(1) 症例 AT 4：9 歳女児で, AT 3 の妹である. 1964 年 12 月 13 日生. 歩行開始 15 力月, 3 歳頃から動摇性歩 行と言語楥慢に気付く. 9 歳, 眼球結膜の毛細血管拉張 に気付き，歩行障害むひどくなったため稆介された. 水 痘, 麻疹, ムンプスは軽症ですみ, DPT, 種痘, ポリオ, BCG のいずれも副反応はなかった.

(2) 症例 AT 5:11 歳男児. 1964 年 6 月 24 日生. 家 系にはこの同胞例 (AT 6, AT 5)以外にはAT はないが, 父方祖父母が癌で死亡している2). 乳児期には異常に気 付かなかったが，初歩 16 力月頃から転倒しや寸かった. 6 歳頃, 動摇性歩行著明で, 9 歳頃眼球結膜充血, 眼球 運動異常を指摘された. 10 歳頃から上気道炎, 中耳炎, 肺炎を絽り返すため，精查目的で紹介された。ポリオ， 種痘，日脳，インフルエンザ，BCG ワクチンは副反応な くすんでいる。 
表 1 Physical findings of three patients at first visit

\begin{tabular}{|c|c|c|c|}
\hline & $\mathrm{AT}-4$ & AT -5 & $\mathrm{AT}-6$ \\
\hline Date & 1974.7 .5 & 1976. 1. 16 & 1976. 2. 1 \\
\hline Age $(y)$ & 9 & 11 & 7 \\
\hline Height $(\mathrm{cm})$ & $121.2(-1.5 \sigma)$ & $124.0(-2.6 \sigma)$ & $110.2(-2.0 \sigma)$ \\
\hline Body weight (kg) & $21.4(-1.4 \sigma)$ & $22.2(-2.2 \sigma)$ & $18.0(-1.5 \sigma)$ \\
\hline \multicolumn{4}{|l|}{ Telangiectasia } \\
\hline conjunctiva & $(+)$ & $(+)$ & $(+)$ \\
\hline auricule & $(-)$ & $(-)$ & $(-)$ \\
\hline Pseudoophthalmoplegia & $(-)$ & $(+)$ & $(-)$ \\
\hline Nystagmus & $(-)$ & $(+)$ & $(-)$ \\
\hline Masked face & $(+)$ & $(t)$ & $(+)$ \\
\hline Drooling & $(-)$ & $(+)$ & $(+)$ \\
\hline Speech & slow & slow & slow \\
\hline Ataxic gait & $(+)$ & $(+)$ & $(+)$ \\
\hline Finger-to-nose-test & disturbed & disturbed & disturbed \\
\hline Romberg's sign & $(+)$ & $(+)$ & $(+)$ \\
\hline Athetose-like movement & $(+)$ & $(-)$ & $(-)$ \\
\hline Pathologic reflex & $(-)$ & $(-)$ & $(-)$ \\
\hline Mental retardation & $(-)$ & $(-)$ & $(-)$ \\
\hline Hepatosplenomegaly & $(-)$ & $(-)$ & $(-)$ \\
\hline Lymphadenopathy & $(-)$ & $(-)$ & $(-)$ \\
\hline
\end{tabular}

(3) 症例 AT 6:7 歳男児. AT 5 の弟である. 1968 年 6 月 7 日生. 乳児期は順調で，種痘, DPT, BCG は副反 応はなかった. 歩行開始は 14 力月で以来動摇性歩行を 示している．兄がATと診断されたので同疾患を疑い来 院した. 易感染性はない.

\section{2. 初診時所見}

1) 身体所見（表 1)：3例ともに身体発育不良で，小 腮性失調症と眼球結膜の毛細血管拡張を認めたが，病的 反射，知能障害はなかった. AT 4 でアテトーゼ様の不 随意運動を, AT 5, AT 6 で流涎をみた. AT 5 は pseu. doophthalmoplegia, 眼振を示し， 3 例ともに典型的な AT と診断した.

2）一般検査所見（表 2)：末梢血白血球数，肝機能検 查, 蛋白分画は異常なく, 脳波所見, 胸部 X楾像む異常 所見は認められなかった. $\alpha$-fetoprotein 值は 3 例とも高 值であった。

3) 免疫学的検査所見 (表 3)

(1) 血清免疫グロブリン値は，AT 5，AT 6 の兄弟に $\operatorname{IgA}, \operatorname{IgE}$ 欠損が認められた。睡液中の $\operatorname{IgA}$ も欠くが secretory component は存在した. 血中抗体価について みると, AT 4 は DT ワクチンの booster 反応は正常,
AT 5, AT 6 注風落䍜患後の抗体上昇良好, 同種血球凝 集素価正常，寒冷凝集反応も 512 倍，64 倍であった。

（2）遅延型皮膚反応は，AT 4，AT 5 がッ反陽性を示 したが, DNCB 感作は 3 例とも成立しなかった。同種皮 㲊移植片拒否反忘は，AT 4 は 20 日で正常, AT 5 は 26 日でやや延長していた。

(3) 末梢血リンパ球マーカーは既報4)のごとく行った. Eレセプター陽性細胞％は正常範囲にあるが，表面免疫 グロブリン陽性細胞\%は３例とも低值を示した．血清中 IgA が久損している AT 5, AT 6 で表面 IgA 陽性細胞\% が低值であった。

(4) PHA, PWM 添加 in vitro 培養による末梢リンパ 球 DNA 合成は既報の方法4で行い，同時に行った健康 成人対照のリンパ球の DNA 合成に対する\%で示した が， 3 例とも有意の低下は認められなかった。

以上の初診時の結果からは, AT 4 は細胞性液性免疫 能ともに保たれており，AT 5, AT 6 は細胞性免疫能は 正常，血清 $\operatorname{Ig} A, \operatorname{IgE}$ 欠損があることがわかった.この 3 例につき, 以後の臨床経過の変遷と免疫学的検查を経 時的に追跡した. 
表 2 Laboratory findings of three patients at first visit

\begin{tabular}{|c|c|c|c|}
\hline & $\mathrm{AT}-4$ & $A T-5$ & $\mathrm{AT}-6$ \\
\hline \multicolumn{4}{|l|}{ Peripheral blood } \\
\hline $\mathrm{Rbc} \quad\left(\times 10^{4} / \mathrm{cmm}\right)$ & 431 & 460 & 480 \\
\hline$(\mathrm{g} / \mathrm{d} l)$ & 12.9 & 12.7 & 13.0 \\
\hline Whe $(. \mathrm{cmm})$ & 7,200 & 10,600 & 7,900 \\
\hline lymph. (icmm) & 3,240 & 2,756 & 1,185 \\
\hline \multicolumn{4}{|l|}{ Blood chemistry } \\
\hline total protein $(\mathrm{g} / \mathrm{d} l)$ & 6.7 & 7.1 & 6.7 \\
\hline albumin $\quad(\%)$ & 66.9 & 59.1 & 63.1 \\
\hline$\alpha_{1}$-globulin $(\%)$ & 1.7 & 4.6 & 3.8 \\
\hline$\alpha_{2}$-globulin $(\%)$ & 9.9 & 10.4 & 11.1 \\
\hline$\beta$-globulin $(\%)$ & 12.4 & 12.5 & 11.1 \\
\hline$r$-globulin $(\%)$ & 9.1 & 13.0 & 12.5 \\
\hline $\operatorname{CrOT}(\mathrm{U})$ & 17 & 19 & 21 \\
\hline (:PT L & 11 & 15 & 15 \\
\hline LDH $\quad(\mathrm{U})$ & 180 & 210 & 200 \\
\hline $\mathrm{Al}-\mathrm{P} \quad\left(\mathrm{L}^{\top}\right)$ & 11.6 & 15.6 & 14.5 \\
\hline$\alpha$-fetoprotein $(\mathrm{ng} / \mathrm{m} l)$ & 690 & 1,090 & 273 \\
\hline \multicolumn{4}{|l|}{ Serological test } \\
\hline CRP & $(+)$ & $2(+)$ & $(-)$ \\
\hline ASLO (T.U.) &.$<50$ & 50 & $<50$ \\
\hline ASK & $\mathrm{nt}^{*}$ & 80 & nt \\
\hline $\mathrm{RA}$ & nt & nt & $(-)$ \\
\hline CHA & $\times 16$ & $\times 512$ & $\times 64$ \\
\hline EEG & normal & normal & normal \\
\hline Chest-Xp & normal & normal & normal \\
\hline
\end{tabular}

*; not tested

3. 3 例の臨床経過（1976 年〜1982 年）

(1) AT 4:易感染性はなかったが，小脳性失調症 は 中等症に進行した. 1982 年 (19 歳) 感染の徴候（副鼻腔 炎）が始まった。

(2) AT 5 : 初診時 (1976 年, 11 歳)以米, 痰を伴う咳 が絶えずり，治療を受けているが，入院を要する程で はなかった. 1977 年から胸部X線上両側気管支应 張 症 を認めている．1979 年 (14 歳)，Transfer Factor (北大 小児科より分与)を 12 单位注射したが，神経学的所見， 感染に対する効果は認められず，血清 $\operatorname{IgA}$ 值も変化し なかった. 1982 年 (18 歳)，つたい歩きも困難となり， 呼吸器感染は重篤化している.

(3) AT 6 : 1976年 6月 (8 歳), 風疹に䍜患後䄪半年 の間上気道炎を繰り返したが，神経症状の悪化はなかっ た. 1979 年 (11歳), 兄と同様に Transfer Factor を 11 単位注射したが，IgA 值の変化や神経症状の改善は認め
られなかった，1982 年 (14 歳)，小腷性失調症は中等 症 で易感染性はない。

\section{3 例の免疫能の推移 (1976 1982 年) \\ (1) 血清免疫グロフリン值 (図 1)：AT 4 は年を追っ} て IgG が低下し, IgM が増加する傾向を示している. AT 5, AT 6 の兄弟の IgA, IgE 欠損は Transfer Factor 治療も無効であったか，感染の徵候のないAT 6 で IgM 高值を示し，感染防御に関倸があるか, subclinical infection を示すものかもしれない.

(2) 末梢リンパ球膜マーカー（表 4)：Eレセプター陽 性細胞は, AT 4 は正常を保っているが, AT 5, AT 6 は 変動している．表面免疫グロブリン陽性細胞は，変動は あるが 3 例ともに低值を示すことが多い．

T細胞亜分画はヒッジ赤血球ロゼット形成後，比重遠 心法により得られた $T$ リンパ球分画につき, 9.65), OKT 
表 3 Immunological findings of three patients at first visit

\begin{tabular}{|c|c|c|c|c|}
\hline & AT-4 & AT -5 & AT -6 & \\
\hline \multicolumn{5}{|l|}{ Serum Ig levels } \\
\hline $\mathrm{IgG} \quad(\mathrm{mg} \mathrm{d} l)$ & 1,008 & 1,130 & 1,240 & \\
\hline $\mathrm{IgA} \quad(\mathrm{mg} / \mathrm{d} l)$ & 328 & $<0.8$ & $<0.8$ & \\
\hline $\mathrm{IgM} \quad(\mathrm{mg} / \mathrm{d} l)$ & 215 & 224 & 274 & \\
\hline $\mathrm{IgD} \quad(\mathrm{mg} / \mathrm{d} l)$ & 18 & 80 & 60 & \\
\hline $\mathrm{IgE} \quad(\mathrm{ng} / \mathrm{m} l)$ & 68 & 0 & 0 & \\
\hline \multicolumn{5}{|l|}{ Complement } \\
\hline $\mathrm{C} 3 \quad(\mathrm{mg} / \mathrm{d} l)$ & 62 & 100 & 78 & \\
\hline $\mathrm{C} 4 \quad(\mathrm{mg} / \mathrm{d} l)$ & 18 & 30 & 24 & \\
\hline $\mathrm{C} 3$ act. $(\mathrm{mg} / \mathrm{d} l)$ & 15 & 66.8 & 27.6 & \\
\hline \multicolumn{5}{|l|}{ Salivary Ig levels } \\
\hline $\operatorname{lgG} \quad(\mathbf{m g} / \mathrm{d} l)$ & 1 & 5 & 3 & \\
\hline $\operatorname{IgA} \quad(\mathrm{mg} / \mathrm{d} l)$ & 6 & $<0.8$ & $<0.8$ & \\
\hline $\operatorname{IgM} \quad(\mathrm{mg} / \mathrm{d} l)$ & 2 & 10 & 5 & \\
\hline Secretory component & $(+)$ & $(+)$ & $(+)$ & \\
\hline \multicolumn{5}{|l|}{$\begin{array}{l}\text { Circulating antibody } \\
\text { isohemagglutinin }\end{array}$} \\
\hline anti-A & 110 & $\times 1,024$ & $\because 512$ & \\
\hline anti-B & $1 / 10$ & $\times 512$ & Y 64 & \\
\hline (blood type) & $(\mathrm{AB})$ & (0) & $(0)$ & \\
\hline Diphtheria & pre, \& post booster & & & \\
\hline antitoxin & $1 / 300 \rightarrow 1 / 30$ & $\mathrm{nt}^{*}$ & nt & \\
\hline Tetanus antitoxin & $1,10 \rightarrow 3$ & nt & nt & \\
\hline Rubella (HI ; & nt & $\times 128$ & $\times 128$ & \\
\hline \multicolumn{5}{|l|}{ Delayed hypersensitivity } \\
\hline $\mathrm{PPD}(0.5 \mu \mathrm{g} / 0.1 \mathrm{~m} l)$ & $(+)$ & $(+)$ & $(-)$ & \\
\hline DNCB & $(-)$ & $(-)$ & $(-)$ & \\
\hline Candida $(1: 10,000)$ & $(-)$ & $(-)$ & nt & control \\
\hline Skin homograft rejection & 20 days & $26 \mathrm{~d}$. & nt & $20 \mathrm{~d}$ \\
\hline PBL surface markers & & & & controls $(\mathbf{m} \pm \mathbf{s d})$ \\
\hline E-RFC $\left(\frac{0}{0}\right)$ & 64 & 68 & 70 & $(67.6 \pm 10.3)$ \\
\hline 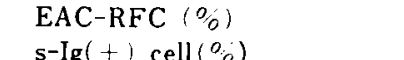 & 14 & 17 & 10 & $(19.7 \pm 7.5)$ \\
\hline \multicolumn{5}{|l|}{ s-Ig $(+)$ cell $\left(a_{0}\right)$} \\
\hline $\mathrm{IgG}$ & 4.1 & 1.0 & $\begin{array}{l}4.0 \\
2.3\end{array}$ & $\begin{array}{r}(13.3 \pm 4.8) \\
(9.2 \pm 4.5)\end{array}$ \\
\hline IgA & 1.0 & 0.5 & 0 & $(5.5 \pm 2.7)$ \\
\hline $\operatorname{IgM}$ & 1.0 & 0.3 & 2.8 & $(4.6 \pm 2.8)$ \\
\hline $\operatorname{IgD}$ & nt & 0.5 & 0.8 & $(1.7 \pm 1.5)$ \\
\hline \multicolumn{5}{|l|}{$\begin{array}{l}\text { In vitro lymphocyte DNA } \\
\text { synthesis }\end{array}$} \\
\hline PHA $(\mathrm{cpm})[\% \text { of normal })^{\#}$ & $54,020 〔 63$ & $17,209(61)$ & $28,919 \quad 103$ & \\
\hline $\mathrm{PWM}(\mathrm{cpm})[\%$ of normal $]$ & $45,000[144]$ & $33,000: 106$ & $29,100(93$ & \\
\hline Lymphnode biopsy & nt & $\begin{array}{l}\text { lymphocyte } \\
\text { depletion }\end{array}$ & $\mathrm{nt}$ & \\
\hline
\end{tabular}

* : not tested

8 : percent of immunofluorescent positive cells with antisera to poly-Ig ( IgG $+\mathrm{A}+\mathrm{M})$

\#: See footnote to Fig. 2. 

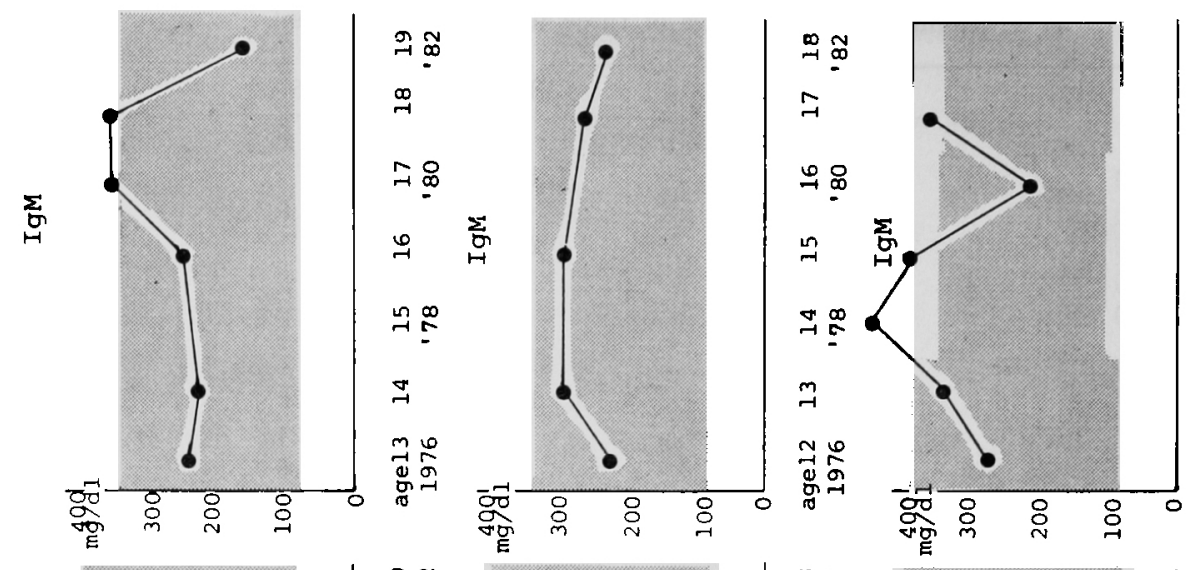

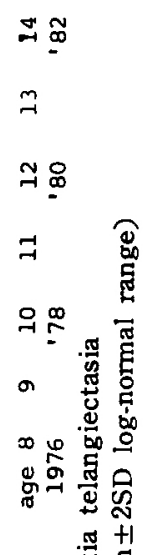
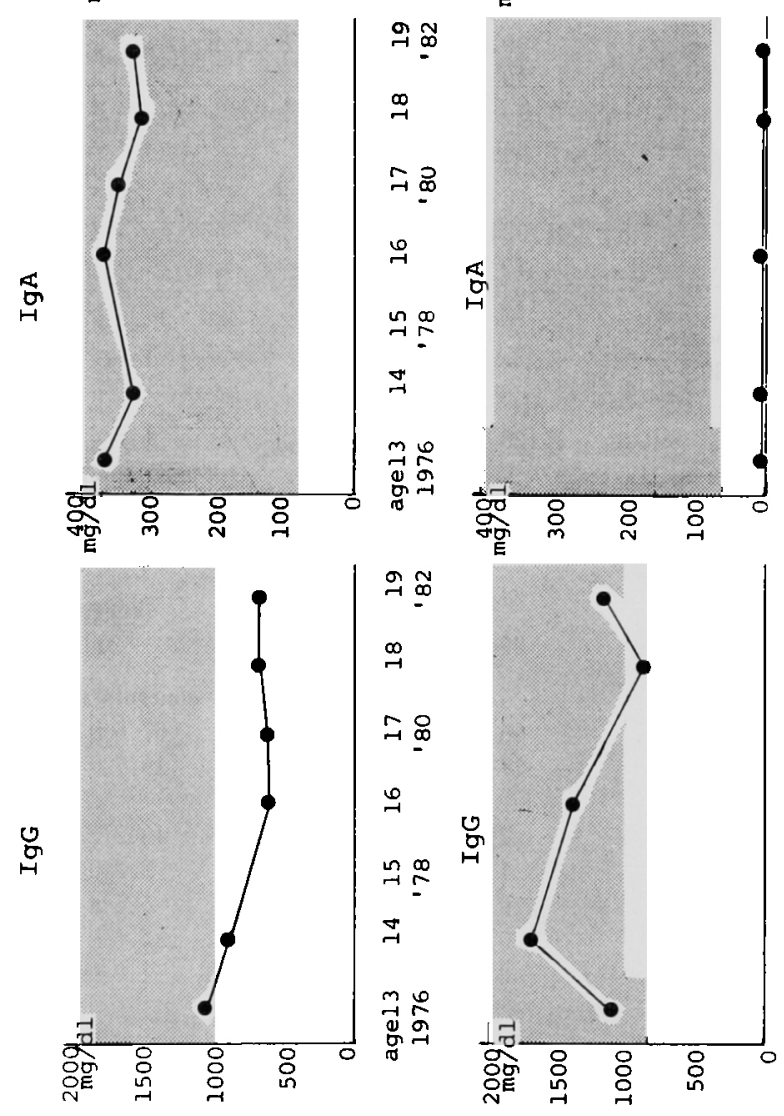

幽

量

晁 
表 4 Surface markers of peripheral blood lymphocyte of three patients with AT

\begin{tabular}{|c|c|c|c|c|c|c|c|c|c|c|c|c|c|c|}
\hline \multirow{2}{*}{ Case } & \multirow{2}{*}{ Date age - } & \multicolumn{5}{|c|}{ Surface Ig bearing cell ${ }^{\circ} 0$} & \multirow{2}{*}{$\mathrm{EAC}-\mathrm{RFC}$} & \multirow{2}{*}{$\mathrm{E}-\mathrm{RFC}$} & \multicolumn{6}{|c|}{ T subset $\#$} \\
\hline & & total-Ig & IgG & $\operatorname{Ig} A$ & $\operatorname{lgM}$ & $\mathrm{IgD}$ & & & 9.6 & OKT3 & OKT4 & OKT6 & OKT8 & $\mathrm{Ia}^{+}-\mathrm{T}$ \\
\hline \multirow[t]{6}{*}{ AT4 } & $7612 y$ & & & & & & 10 & 64 & & & & & & \\
\hline & $7713 y$ & & & & & & 28 & 76 & & & & & & \\
\hline & $7814 y$ & 5.3 & 4.1 & 1.0 & 1.0 & $n t^{\prime}$ & 8 & 54 & & & & & & \\
\hline & $8017 y$ & 5.7 & $2.5^{\circ}$ & 7.2 & 2.7 & 2.6 & 38 & 67 & & & & & & $9.4^{* *}$ \\
\hline & $' 8118 y$ & 6.0 & 4.5 & 4.3 & 4.8 & $0.7^{*}$ & 16 & 80 & & & & & & $12.7^{* *}$ \\
\hline & $8219 y$ & 3.9 & 3.1 & 1.0 & 1.5 & $0.5^{\circ}$ & 11 & 86 & 97.5 & 90.1 & $9.3^{*}$ & 0 & $84.7^{\circ}$ & 3.7 \\
\hline \multirow[t]{5}{*}{ AT5 } & $77,13 y$ & & & & & & 41 & 68 & & & & & & \\
\hline & $7814 y$ & $2.3^{\circ}$ & $1.0^{\circ}$ & $0.5^{*}$ & $0.3^{\circ}$ & $0.5^{*}$ & 20 & 50 & & & & & & \\
\hline & $8016 y$ & 10.5 & 8.5 & $0.5^{\circ}$ & 1.0 & $0.5^{\circ}$ & nt & $44^{\circ}$ & & & & & & \\
\hline & $8117 y$ & $2.5^{*}$ & $0.5^{\circ}$ & 1.0 & $0.5^{\circ}$ & $0^{*}$ & 9 & $40^{\circ}$ & & $46.0^{\circ}$ & $27.4^{*}$ & 0 & 26.3 & $21.3^{* *}$ \\
\hline & $8218 y$ & 8.5 & $2.6^{\circ}$ & $0.7^{\circ}$ & 3.4 & $0.7^{\circ}$ & 40 & 85 & 90.0 & $74.7^{*}$ & $43.4^{*}$ & 0 & 26.5 & $9.5^{* *}$ \\
\hline \multirow[t]{6}{*}{ A T6 } & $77^{\prime} 9 y$ & & & & & & 39 & 70 & & & & & & \\
\hline & $7810 y$ & 4.3 & $2.6^{\circ}$ & 6.7 & 1.5 & $n t$ & 31 & $41^{\circ}$ & & & & & & \\
\hline & ' $80.12 y$ & $1.5^{\circ}$ & $1.0^{\circ}$ & $0.5^{\circ}$ & 1.0 & $0.5^{*}$ & 48 & 47 & & & & & & \\
\hline & $8113 y$ & $2.5^{*}$ & $1.0^{\circ}$ & 1.5 & 1.5 & $0^{*}$ & 10 & $35^{\circ}$ & & & & & & $10.0^{\circ *}$ \\
\hline & $8214 y$ & 5.3 & nt & $0.8^{\circ}$ & $\mathrm{nt}$ & nt & 19 & 56 & 95.0 & $63.0^{\circ}$ & $50.0^{*}$ & 0 & $8.3^{*}$ & $7.5^{\circ *}$ \\
\hline & & 13.3 & 6.8 & 5.5 & 6.3 & 2.5 & 19.7 & 67.6 & 96.3 & 92.1 & 69.3 & 0.4 & 27.1 & 3.2 \\
\hline \multicolumn{2}{|c|}{ Controls $m \pm S \mathrm{~L}$} & \pm 4.8 & \pm 2.0 & \pm 2.3 & \pm 2.7 & $\therefore 0.8$ & \pm 7.5 & \pm 10.3 & \pm 3.1 & \pm 4.0 & \pm 5.5 & \pm 0.4 & \pm 8.6 & \pm 1.4 \\
\hline
\end{tabular}

$\$$ : Percent of immunofluorescent positive cells with antisera to polyvalent $\operatorname{Ig}+\lg G+\lg A+\operatorname{Ig} M$.

\#: Percent of immunofluorescent positive cells among $\mathrm{T}$ cell-fraction with six monoclonal antibodies.

- : The values are significantly lower than the cuntrol group mean $<2 S D$ ।

$\cdots:$ The values are significantly higher than the control group mean $(>2 S D)$ ).

3, OKT 4, OKT 6, OKT 8 (Ortho-mune 社製)6), およ びヒト Ia-like antigen に対する monoclonal 抗体 (NL12 ，マウス $r 2 \mathrm{a})^{7)}$ を用い，間接螢光抗体法で検討した。 Ia 陽性 T 細胞は 3 例とも増加の傾向を示しており，本症 における細胞の未熟性を物語るものかもしれないが8， その意義つけについては検討中である.

AT 4 は 1982 年 (19 歳) OKT 4/OKT 8 比が逆転して おり今後の動きが注目される.AT 5, AT 6 は 9.6 陽性 細胞 $90 \%$ 以上の T 分画でありながら OKT 3 の比率が 低く，末熟 T の増加が疑われるが，Panning 法などに より $\mathrm{T}$ 細胞亜分画を分離して検討寸る必要があると考え る.

(3) 非特異的 mitogen を用いたリンパ球 in vitro DNA 合成 (図 2)：1976 年〜1978 年は既報4)のごとくリ ン八゙球 $5 \times 10^{5}$, PHA $10 \mu \mathrm{g}$, PWM $25 \mu \mathrm{g}$ 添加, $15 \% \mathrm{fcs}$ 加 RPMI 1640 で最終 $1 \mathrm{~m} l$ で培垗. 1979 年以降はリンパ 球数 $1 \times 10^{5}$, PHA $5 \mu \mathrm{g}$, PWM $1.25 \mu \mathrm{g}$, Staphylococcus aureus Cowan I (IgG sorb; Enzyme 社製) (Staph. a. と略 $) \times 5,000$ 添加, 最終 $200 \mu l$ で培盖した。比較の
ため，同一日に行った健康成人対照のリンパ球の結果に 対する百分率で示した.

AT 4 は PHA (T mitogen), PWM (T 依存性 B mitogen) に対する反応は 18 歳（1981 年）まで正常を保 っていたが，19 歳（1982 年）は低下傾向にある.

AT 5 は 16 瓷（1980年）から PHA，PWM に対する 反応は著明な低下を続けて㧍り，Staph。. a. (T 非依存性 B mitogen) に対する反応も異常低值を示す.

AT 6 は PHA, PWM, Staph. a. とも軽度の低下を示 していたが, 14 歳 (1982 年), 低下が顕著になってきて いる.

(4) in vitroリンパ球培苓による免疫クロロフリン産生 能亡 T-B 共同作用の検討：末梢リンパ球の免疫ブロブ リン産生能は既報9のごとく, PWM 添加, 6 日閒培㕠後, 細胞質内免疫グロブリン合成細胞％[cytoplasmic total Ig (IgG+IgA+IgM) (cytoplasmic total Ig と略), cytoplasmic IgA と表す]を螢光抗体法で，また培養液 中に分必された IgA，IgG 量をラジオイム/アッセイて 測定した. $\mathrm{T}-\mathrm{B}$ 共同作用は, $\mathrm{E}$ 口ゼッタ法により $\mathrm{T}, \mathrm{B}$ 


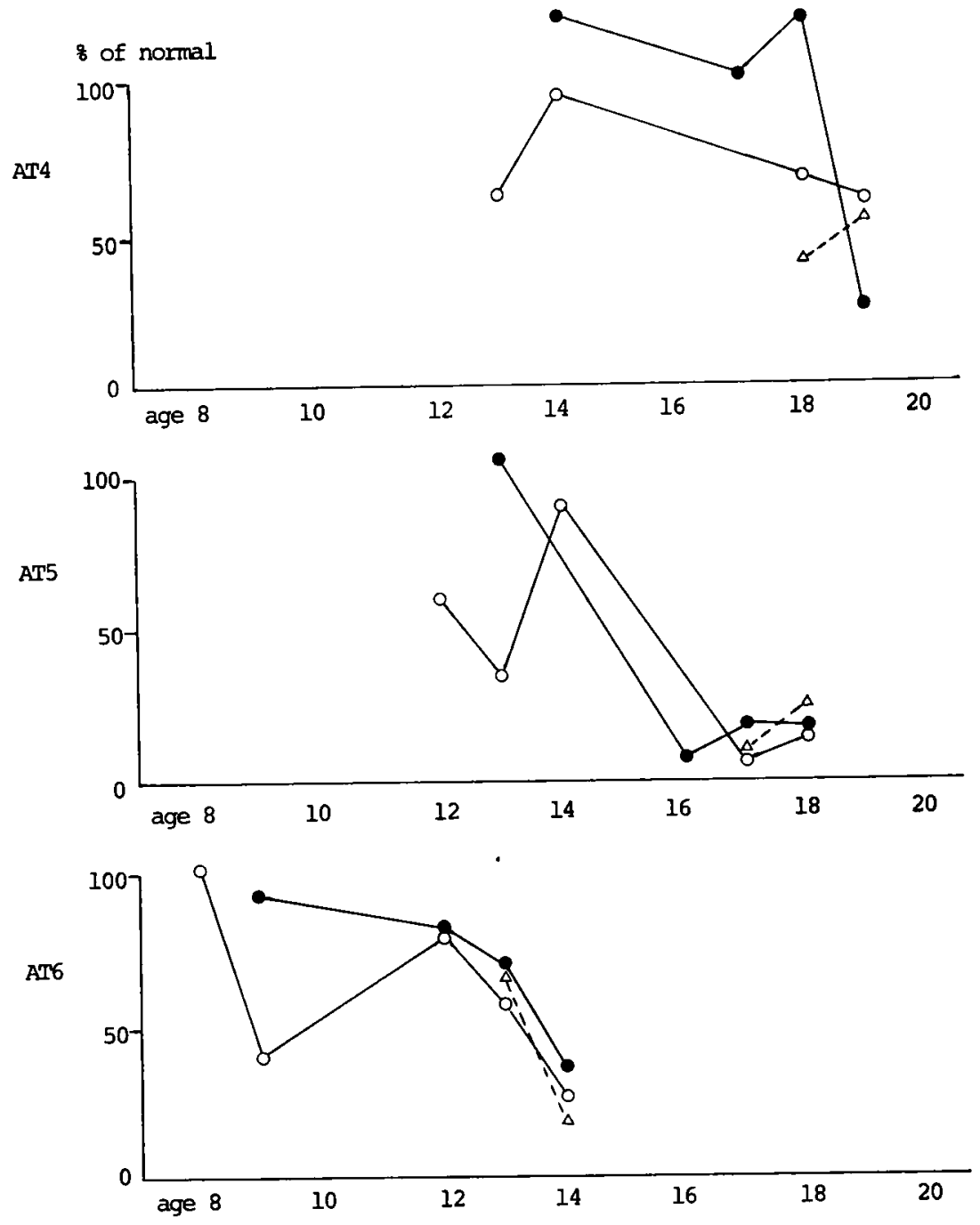

Lymphocyte DNA synthesis induced by PHA (०-0),PWM(৫-) and Staph.a. $(\Delta-\Delta)$ was determined by ${ }^{3} \mathrm{H}-\mathrm{TdR}$ incorporation and expressed as of normal, which was calculated by (patient's uptake) $\div$ (control's uptake) $\times 100$. The normal range of "z of normal" of lymphocyte cultures stimulated by PHA,PWM and Staph.a. in 21 age matched controls (from 8 to 20 years old) were $94.1 \pm 37.0,104.5 \pm 39.4$ and 87.8 \pm 30.0 (means $\pm 2 S D$ ), respectively.

図 2 Follow up study of in vitro lymphocyte culture of three AT-patients

分画した後, 患児, 母親, 健康人対照の間で $\mathrm{T}: \mathrm{B}=$ $1: 1 の$ auto, allo の組み合わせで培養し検討した. 部は培養終了時のリンパ球 DNA 合成 $\left({ }^{3} \mathrm{H}-\mathrm{TdR}\right.$ 取り込 み), 生存リンパ球数 (trypan blue dye exclusion) を 测定した.

この結果, 未分画リンパ球培養については AT 4 は正
常で，血清 IgA，IgE 欠損を示す AT 5, AT 6 では 1979 年測定時 cytoplasmic IgA 合成は正常, IgA 分泌障害を 示した. 一方 1980 年の結果では cytoplamic IgA の合 成む低下してきている(表 5).

T-B 細胞 co-culture $の$ 結果, AT 4 の B 細胞分画 (以 下患児 $B$ ) は, 患児 $T$ 細胞分画 (患児 $T$ ), 対照 $T$ 細胞 
表 5 In vitro immunoglobulin production in PWM-stimulated lymphocyte

\begin{tabular}{|c|c|c|c|c|c|}
\hline \multirow{2}{*}{ Case } & \multirow{2}{*}{ I)ate } & \multicolumn{2}{|c|}{ cytoplasmic Ig synthesis $\left({ }^{\prime \prime} 0\right)$} & \multicolumn{2}{|c|}{ Ig secreted $n g(m l$ : } \\
\hline & & total- $\mathrm{Ig}_{\mathrm{K}}^{\S}:$, cell & $\operatorname{Ig} A, 1$ cell & $\operatorname{Ig} G$ & $\lg A$ \\
\hline \multirow[t]{2}{*}{ AT4 } & $5-30-' 80$ & 29.3 & 5.6 & 6,400 & 2,010 \\
\hline & $11-7-80$ & 21.2 & 4.8 & 2,800 & 2,650 \\
\hline \multirow[t]{2}{*}{ AT5 } & $7-13-79$ & 28.2 & 6.6 & 1,680 & $<60^{*}$ \\
\hline & $10-24-' 80$ & 6.4 & $0.4^{*}$ & 870 & $<90^{*}$ \\
\hline \multirow[t]{2}{*}{ AT6 } & $7-13-79$ & 23.4 & 2.9 & 4,050 & $\left\ulcorner 60^{*}\right.$ \\
\hline & $1-25-80$ & 34.7 & $0.7^{*}$ & 4,000 & $100^{*}$ \\
\hline \multirow{2}{*}{\multicolumn{2}{|c|}{$\begin{array}{r}\text { Controls } \\
(n=71)\end{array}$}} & $13.3 \pm 5.8$ & $5.1 \pm 2.0^{*}$ & $3,151^{\circ}$ & $1,798^{\circ}$ \\
\hline & & & & $(741-12,882)$ & $562-5,623$ \\
\hline
\end{tabular}

3: See footnote to Table 4.

$\#:$ The arithmetic means $\pm 1 S 1$.

: : The geometric means $\pm 2 S D$ log-normal range.

*: The values are significantly lower than the control group mean $(<2 S D)$.

Peripheral blood lymphocyte obtained from three $\Lambda \mathrm{T}$-patients, were cultured with PWI as previous report. Cytoplasmic Ig synthesis was assayed hy immunofluorescence technique and secretion of $\mathrm{Ig}$ into the culture supernatant was determined by radioimmunoassay, as previous report.

分画 (対照 $T$ )，母親 $T$ 細胞分画（母親 $T$ ）のいずれと 組み合わせても, cytoplasmic total Ig 合成, cytoplas. mic IgA 合成ともに低下傾向を示した. 一方 IgA 分必 は正常であるが，IgG 分泌は有意に低下していた．患児 の血清 IgG が in vivo でむ経時的任下している現象 （図 2）と考え合わせ，また患児T分画は対照および母親 のB分画の免疫グロブリン産生を正常に help すること から IgG-B cell の異常を疑放せた（表 6).

AT 5 は血清 IgA 欠損を示すが, T, B 分画後, T, B そ れぞれの組み合わせで培養した結果，患児 $\mathrm{B}$ は患児 $\mathrm{T}$, 対照 $\mathrm{T}$ ，母親 T の組み合わせのいずれについても IgA のみならず IgG 産生も合成, 分泌障害を示した。一方患 児Tは母親および対照 B 分画の IgG, IgA 産生の helper 能を保っていた。この結果からは B cell 障害を示唆し た (表6).

AT 6 も血清 IgA 欠損を示すが, T, B 分画後患坚 B は 患児 $T$, 対照 $T$ ，母親 $T$ のいずれの組み合わせでも， cytoplamic total Ig, IgA 合成がとるに低下しており， IgA 分泌も認められす，さらに IgG 分必も有意に低下 していた。一方患児 Tの母親, 対照 B cell に対する IgG, IgA 産生の helper 能は異常なかった. 以上から B cell 障害を思わせた（表 6).

以上 3 例の結果をみると, helper $\mathrm{T}$ 能はどれも正常だ が, AT 4 は in vivo での IgG 低下と一致した IgG-B cell の機能低下を示し, AT 5, AT 6 は in vivo では IgA 欠損のみで IgG 正常であるにもかかわらず, IgA ばかり でなく IgGも含めた B cell 障害を示していた.

そこで T, B 分画操作が患者のリンパ球に与える影響 を検討した (表 7). $\mathrm{T}: \mathrm{B}=1: 1$ で co-culture を行って いるため，対照では未分画リンパ球培養に比べて対照 $\mathrm{B}+$ 対照 T の co-culture で cytoplasmic total Ig, IgA 合成は著明な变化はなく, IgG, IgA 分必量はむしろ增加 している．患児は 3 例とも，患児 $B+$ 患児 $T$ は未分画リ ンパ球に比べて cytoplasmic total Ig, IgA 合成は著明 に減少し, IgG 分泌も分画後減少した. 培荃終了時の生 存リンパ球数は分画前と分画後で差が無いが，AT5 で DNA 合成が分画後著明に低下した。これらの結果から T-B 分画撂作により， AT 患児 B 細胞分画は容易に障害 を受けることが疑われ，ATの B 細胞の易障害性を表す 現象として興味深い.T-B co-culture 法をこの上うな易 障害性をもつ患者リンパ球の検討に用いる際，結果の評 価には慎重でなければならないと思われた。

選択的 IgA 欠損症および抗㾏攀剂による低 IgA 血症 について従来より PWM 添加 in vitro B-cell 分化能が 検討され, in vitro では IgA 合成, 分泌が認められるも $の^{10)}$, 細胞倎内 IgA 合成細胞までは分化するが分泌し ない症(例"1)，IgA 合成も認められない症例(1)など heterogeneity が報告されている. IgA 欠損を伴う ATについ 
表 6 Results of co-culture with T, B cell fraction of AT-patients

\begin{tabular}{|c|c|c|c|c|c|c|c|c|c|c|}
\hline \multirow{2}{*}{$\begin{array}{l}\text { Case } \\
\text { (Date. }\end{array}$} & & \multicolumn{3}{|c|}{ patient's B cell } & \multicolumn{3}{|c|}{ control's B cell } & \multicolumn{3}{|c|}{ mother's B cell } \\
\hline & & t pat. T & $+\operatorname{cont} . \mathrm{T}$ & $\because$ moth. T & + pat. $T$ & + cont $T$ & + moth. $T$ & + pat. $T$ & + cont. $T$ & + moth.T \\
\hline & cyto-Ig: ${ }_{6}^{\prime \prime}=$ & 3.9 & 4.8 & 6.3 & 35.0 & 25.2 & 31.0 & 13.3 & 25.5 & 12.4 \\
\hline AT4 & cyto- $\operatorname{Ig} A\left({ }^{\prime}\right)_{1}$ & $1.1^{*}$ & 1.0 & 2.0 & 6.9 & 8.4 & 10.5 & 2.1 & 3.8 & 6.3 \\
\hline \multirow[t]{3}{*}{$11-7-80$} & IgG secreted ${ }^{\S}$ & $760^{\circ}$ & $680^{*}$ & $670^{*}$ & 4,800 & 6,250 & 4,600 & 5,200 & 4,800 & 4,900 \\
\hline & IgA secreted ${ }^{5}$ & 2,470 & 2.550 & 2,350 & 6,200 & 6,100 & 6,000 & 3,400 & 4,400 & 4,900 \\
\hline & cyto-Ig/oi & $1.5^{*}$ & $1.1^{*}$ & 2.4 & 19.5 & 20.8 & 22.8 & 26.2 & 13.6 & 14.0 \\
\hline AT5 & cyto-IgA $(\%)$ & $0^{*}$ & $0^{*}$ & $0^{*}$ & 3.8 & 4.7 & 5.6 & 5.2 & 4.4 & 4.4 \\
\hline \multirow[t]{3}{*}{$(10-24-' 80)$} & IgG secreted & $170^{*}$ & $108^{*}$ & $120^{*}$ & 2,140 & 4,000 & 2,600 & 5,200 & 2,740 & 2,600 \\
\hline & IgA secreted & $<60^{*}$ & $<60^{*}$ & $<60^{*}$ & 2,850 & 4,000 & 4,000 & 2,600 & 1,500 & 1,640 \\
\hline & cyto- $\operatorname{Ig}\left({ }^{0}\right)$ & $0.7^{*}$ & 4.1 & $1.0^{*}$ & 14.0 & 13.2 & 6.6 & 20.9 & 13.6 & 14.0 \\
\hline AT6 & cyto- $\operatorname{Ig} A(\%)$ & $0.01^{*}$ & $0.01^{*}$ & $0^{*}$ & 3.8 & 4.0 & 2.7 & 5.6 & 4.4 & 4.4 \\
\hline \multirow[t]{2}{*}{$(7-13-79)$} & IgG secreted & $1,080^{*}$ & $780^{*}$ & 1,100 & 1,960 & 3,300 & 2,100 & 4,700 & 2,740 & 2,600 \\
\hline & IgA secreted & $<60^{*}$ & $<60^{*}$ & $<60^{*}$ & 1,320 & 1,200 & 1,240 & 1,220 & 1,500 & 1,640 \\
\hline
\end{tabular}

\#: Cytoplasmic Ig synthesis was assayed by immunoflourescence technique. Cyto-Ig and cyto-IgA $(+)$ cell are refered to the percent of immunofluorscent positive cells with antisera to polyvalent $\lg (\operatorname{IgG}+\operatorname{IgA}+\operatorname{IgM})$ and to $\operatorname{IgA}$, respectively. The normal range of cyto-Ig and IgA synthesis in 71 control co-cultures with autologous and allogeneic combinations were $18.7 \pm 8.3^{\circ}$ ond $3.2 \pm 1.0 \%$ (the arithmetic means $\pm 1 S D$ ), respectively.

1 : Secretion of $\operatorname{lgG}$ and $\operatorname{IgA}$ into the culture supernatant was determined by radioimmunoassay and expressed as $\mathrm{ng} \mathrm{m} /$. The normal range (the geometric means $\pm 2 S D$ log-normal range) of IgG and IgA secretion in 71 control co-cultures with autologous or allogeneic combinations were $3,968 \mathrm{ng} / \mathrm{ml}(977$ to $10,218 \mathrm{ng} / \mathrm{ml})$ and $2,173 \mathrm{ng} \mathrm{m} l(537$ to 8.709 $\mathrm{ng} / \mathrm{m} l$ ), respectively.

*: The values are significantly lower than the control group mean $(<2 S D)$.

ては in vitro IgA 合成分必が認められたと報告されてい るが(1), 我々の2 例では細胞質内 IgA 合成は認められ たが培盖液中への IgA 分泌は認められなかった。また従 来より $\mathrm{T}, \mathrm{B}$ 分画を用いた co-culture を用いて IgA-B cell 障害, suppressor $\mathrm{T}$ の存在などが IgA 久損の病因 として報告されているが, AT に伴う IgA 欠損では現在 まで co-culture の検討の報告は極めて少ない，我々の 検討した例ではいずれも T cell helper 能は異常なかっ た. B-cell 機能については, 1 例に IgG-B cell 障害, 2 例で B.cell 障害を示唆する結果を得たが, その際分画操 作に伴う AT の B-cell の易障害性という新知見を得, B-cell 機能異常については確定できなかった.

\section{III. 考按}

Ataxia-telangiectasia は全身器官にわたる多彩な 症 状を呈し，反復呼吸器感染や若年での悪性腫瘍多発のた め短命であるが，近年の細胞レベルでの研究で，細胞の DNA 代謝に必要な酵素の異常が病因論として有力にな っている12,13)．それに関する現象として，臨床的に放射 線に感受性の高いことが知られており ${ }^{14,15)}$, in vitro で もリンパ球，線維芽細胞が X楾やある種の薬剤に感受性
が高いことや ${ }^{16,17)}$ ，染色体の離断，転座など ${ }^{18,19)}$ が報告 されている. 剖検でみられる巨核細胞も細胞の分裂障害 の結果と考えられ ${ }^{20)}$, 血清中の $\alpha$-fetoprote ${ }^{21)}$, 癌胚抗 原 ${ }^{22)}$ 高値とともに AT の細胞の未熟性を示すと考えら れ, また皮膚の白斑, 萎縮, 白髪, 動脈硬化などの早発老 化 ${ }^{20)}$ も細胞の DNA 代謝異常によるものかもしれない.

AT の神経症状は進行性で, 長ずれば障害が強くなる が，免疫能はどうであろうか．免疫不全の合併率や種類 は報告者によって異なるが，それは患者の年龄，検查方 法の違いによるむのと考えられる.我々の長期追跡でき た 6 例は，おのおのいくつかの免疫学的異常をもってい たが,その heterogeneity, 進行性について論じてみた W.

各症例の発症年龄，易感染性の有無，転帰を示す．年 代により免疫学的検查法も変わってきているため, 受診 年を表にした（図3）.

慢性呼吸器感染は AT 1, AT 5 の 2 例にあり, AT 3, AT 4 では 10 歳代後半になって出現した，悪性新生物は AT 2 の-cell ALLの1例である.

初回検查時の免疫能とその後の推移を検討したとこ ろ; 
松岡・Ataxia-telangiectasia 伴う免疫不全症の長期予後

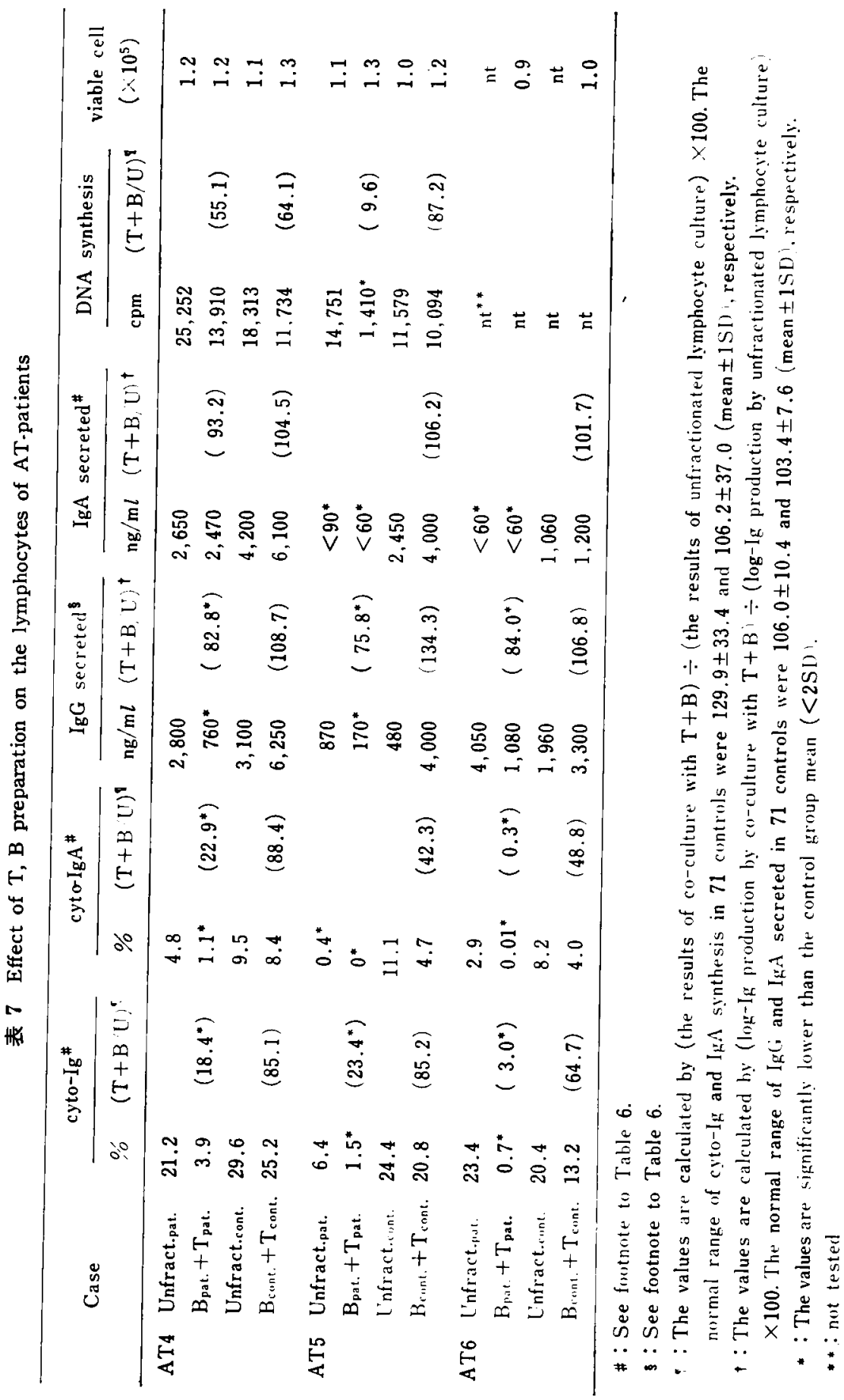




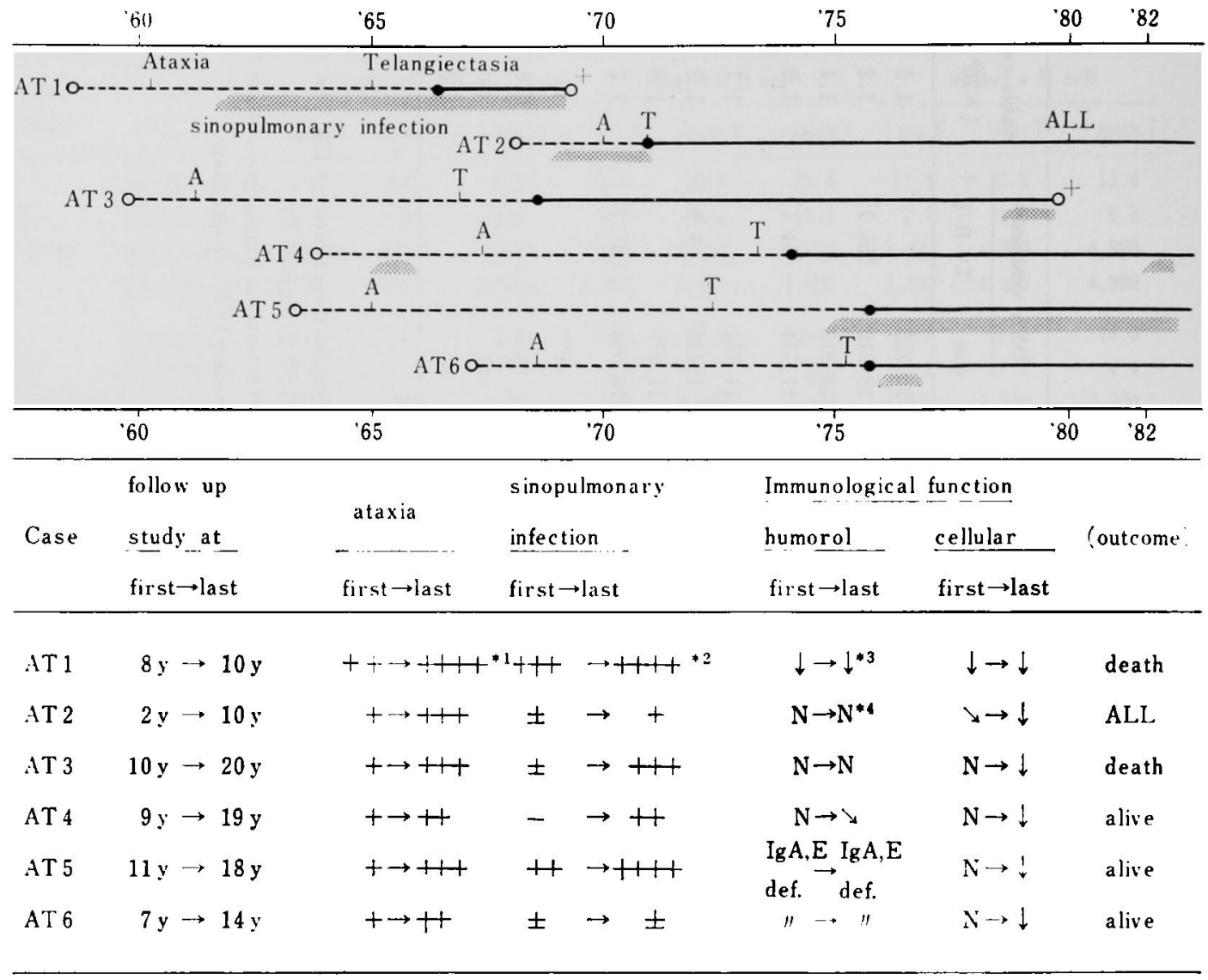

- $1 ; \quad+$ : mild ataxia, ++++ : pronounced ataxia

* $2 ; \quad-: \leq 4$ episodes of URI symptoms per year

$\pm:>4$ episodes of URI symptoms per year not requiring medical care

+ : recurrent sinusitis and/or $\geq 4$ URIs per year requiring outpatient visits

++ : chronic sinusitis or 2-3 episodes of pneumonia

$++t>4$ episodes of pneumonia

+++ : bronchiectasia

$(* 1, * 2:$ Ref. 23$)$

* 3 ; decreased, * 4 ; normal

The schema (the upper half) summarized onset of Ataxia(A) and Telangiectasia( $T$ ), and the episodes of sinopulmonary infection(\%). . . The open circle(O) represents birth date and the closed circle(•) represents the date of first visit.

The table (the lower half) summarized clinical course and the results of immunological studies from first visit to the last visit or the time of this report.

図 3 Summary of long-term follow up study of six patients with AT

AT 1 は 8 歳時すでに低 $\operatorname{IgA}, \operatorname{IgG}$ 血症, 細胞性免疫 能低下があり，早くより易感染性を呈し反復性呼吸器感 染のため 10 歳で死しした.

AT 2 は 7 歳時, 液性免疫能は正常, 遅延型皮膚反応
低下, リンパ球数減少などの細胞性免疫能减㐷を示して いたが, 10 歳, T cell ALLを発症した。その 1 カ月前の 時点で PHA, PWM によるリンパ球芽球化能などT cell 機能も著明に低下したが，一方血清免疫グロブリン值は 
正常であった.

AT 3 は 10 歳時, 液性細胞性免疫能ともに正常であっ たが, 18 歳から始まった難治性呵吸器感染のため 20 歳 で死亡した，死亡前は，遅延型皮慮反応陰性、PHA, PWM に対するリンパ球反応の著明な低下など稩胞性免 疫能の著明な低下を示した。

AT 4 は 9 歳時, 液性細胞性免疫能に異常はなかった が, 年を追って血清 IgG の減少を示した. 18 歳をで末 梢リンパ球 subpopulation, PHA, PWM 刺激 in vitro リンパ球 DNA 合成, PWM 刺激 in vitro 免疫グロブリ ン産生は正常であったが，19歳には in vitro リンパ球 DNA 合成能の低下をきたし，同時に末梢リンパ球 $\mathrm{T}$ subset の OKT 4/OKT 8 比の逆転を示した. 臨床的に も副鼻腔炎が始まった。

AT 5, AT 6 の兄弟は, 11 歳, 7 歳時, 細胞性免疫能 は異常なく, IgA, IgE 欠損を示した。.2例とも IgG は正 常範囲内ではあるが年を追って低下傾向を示し，末梢り ンパ球Eレセプター陽性細胞も変動しながら低下してい る. PHA, PWM 添加 in vitro リンパ球 DNA 合成は, AT 5 では 16 歳から著明に低下したが，AT 6 は 14 歳か ら低下している. PWM 刺激 in vitro リンパ球免疫グロ ブリン産生能は, 未分画リンハ球培美で AT 5 は 15 歳 時, cytoplasmic IgA 合成細胞は正常であったが，16 歳 時は低下しており，AT 6 も 11 歳で正常，12 歳で低下し ている. AT 5 は T-B co-culture の結果については, T, B 分画操作後の B-cell の異常が強く出, みせかけの Bcell 異常があるため結論できないが, 最近行った未分画 リンパ球の T非依存性 B mitogen (Staph. a.) 添加 in vitro リンパ球 DNA 合成も悪いところから B-cell 異常 が始まったおそれもある．この時点の血清 IgG, IgM は 正常範囲にはあるが, 注意哚く経過をみたい. 18 歳, 気 管支搪張症を伴う肺炎のため軽度呼吸困難がある。

AT 6 は 11 歳時, PHA, PWM 刺激リンパ球 DNA 合 成は正常で, PWM 刺激 in vitro 免疫グロブリン産生能 検査で B-cell 異常を示していたが, 14 歳, Staph. a., PHA, PWM 刺激によるリンパ球 DNA 合成能が低下し た. 臨床的には血清 IgG, IgM は保たれており，感染傾 向はない.

このように 6 例の免疫能異常は症例ごとに症状む発現 時期も異なっていたが，全例進行性に低下した。 そのス ピードもやはり症例ごとに異なっていたがいずれる 10 歳代後半には細胞性免疫能の低下が認められた。

さらに T cell ALL 発症例の発症 1 力月前, 20 歳で感
染死した例の死亡数日前の T cell 能は著明な低下を示 したが，両者ともに血清免疫グロブリン值は保たれてい たことからも，T cell 機能不全が AT の免疫不全として 重要で, AT の感染死, 腫瘍化に関連が樑いと考えられ る.

その $\mathrm{T}$ cell 械能異常の始まる時期をとらえる指標と して, 現在のところ PHA, PWM 添加 in vitro リンパ球 DNA 合成能の検討が最も有力であると思われる.また, T subset の OKT パターン, Ia-like antigen 陽性細胞の 異常も認められることから，それぞれの紏胞分画の機能 解析も必要で, 今後さらに $\mathrm{NK}$ 細胞, $\mathrm{K}$ 細胞活性なども 含めて細胞性免疫能を詳細に検討し, AT の生命予後に 重大な影響のあるものが何か探りたい.

AT の根本的治療法のない現在, 臨床免疫学的に追跡 し, 致死的感染, 悪性腫湯化に至る何らかの免疫異常の 出現時期を的確にとらえ，その異常を治療するか, 進行 を遅らせる手段を考えなければならない.

T cell 異常に対して試みられた Transfer Factor ${ }^{24,25)}$, Thymic factor ${ }^{26)}$, 骨髄移植, 胸腺移植, 胎皃肝移植 ${ }^{27)}$ な ど必ずしるよい結果は得られていない，しかし分子生物 学, 遗伝子操作技術などの進步に伴い, 近い将来根治的 治療が開始されることも期待され，進行性兔疫不全状態 を長年にわたって詳しく解析し，感染死に至る重大な免 疫不全状態が起こる critical point を的確にとらえる方 法を見出すことは必要であろうと考える。

\section{IV. 小 括}

典型的な ataxia-telangiectasia の自験 6 例について， 臨床免疫学的に長期予後を検討した．免疫不全状態の程 度と発現の時期は症例ごとに異なっていたが，いずれむ 進行性に低下し, 10 歳代後半に重篤化した．感染死や悪 性腫崵化と関連深いのは, 細胞性免疫能の低下であり, その低下の指標として PHA，PWM によるリンパ球 DNA 合成能検査が有力である.

最後に, Transfer factor をご供与いただいた北海道大 学小児科松本修三教授，モノクロナル抗体をご供与いた だいた愛知がんセンター上田竜三博士に墚謝いたしま す.

稿を終えるにあたり，ご校閲を賜った鈴木榮教授に深 謝いたします。

本論文の要旨は第 9 回日本臨床免疫学 会 総 会 (1981 年, 東京) で発表した。 
1) Boder, E. : Ataxia-telangiectasia; Some historic, clinical and pathologic observations. Birth Defect, $11: 255 \sim 270,1975$.

2）松岡道子・鳥居新平・松岡 宏 ·岡田純一・宇理 須厚雄・佐藤千寿子・平林紀男 : ataxia-telangiectasia を伴う免疫不全症の長期予後. 第 1 編, 剖検 2 例の臨床経過, 免疫能, 病理所見の比較検 討. 投稿中

3) 松岡道子・松岡 宏・岡田純一・鳥居新平・並川 玲子：ataxia-telangiectasia 䘮伴う免疫不全症の 長期予後. 第 2 稨, $T$ cell malignancy を発症し た 1 男児例. 投稿中.

4) 松岡 宏 · 岡田純一 - 鳥居新平 - 松岡道子 - 他 6 名：抗痙彎剤服用中のてんかん患児における低 IgA 血症の免疫学的検討. 第 1 編, B 細胞分化能 について. アレルギー, $30: 183 \sim 189,1981$.

5) Kamoun, M., Martin, P.J., Hansen, J.A., Brown, M.A., Siadak, B.A. and Nowinski, R. C. : Identification of a human $T$ lymphocytes surface protein associated with the E-rosette receptor. J. Exp. Med., $153:$ 207 212, 1981.

6) Reinherz, E.L., Kung, P.C., Goldstein, G., Levey, R.H. and Schlossman, S.F. : Discrete stages of human intrathymic differentiation: analysis of normal thymocytes and leukemic lymphoblastes of T-cell lineage. Proc. Natl. Acad. Sci. USA, $77:$ 1588 1592, 1980.

7) Ueda, R., Tanimoto, M., Takahashi, T., Ogata, S., Nishida, K., Namikawa, R., Nishioka, Y. and Ota, K. : Serological analys is of cell surface antigens of null cell acute lymphocytic leuke. mia by mouse monoclonal antibodies. Proc. Natl. Acad. Sci. USA, $79: 4386 \sim 4390,1982$.

8) Williams, R.C., Webster, A.D.B., Morito, T. and Greaves, M.F. : T lymphocyte subpopulations and Ia-positive $T$ cells in patients $w$ ith immunodificiency. Clin. exp. immunol., 42 : 355 363, 1980.

9) 松岡 宏. 岡田純一・松岡道子・鳥居新平・高橋 利忠：抗㾏剂服用中のてんかん患者における低 IgA 血症の免疫学的検討. 第 2 編, T-B 協同作用 について.アレルギー, $30: 259 \sim 265,1981$.
10) Wu, L.Y.F., Lawton, A.R. and Copper, M.D. : Differntiation capacity of cultured $B$ lymphocytes from immunodeficient patients. J. Clin. Invest., $52:$ 3180 3189, 1973.

11) Waldmann, T.A., Broder, S., Krakauer, R., Durm, M., Meade, B. and Goldman, C. : Defect in $\operatorname{IgA}$ secretion and in IgA specific suppressor cells in patients with selective IgA deficiency. Trans. Ass. Amm. Physic., 89 : 215 224, 1976.

12) Edwards, M.J. and Taylor, A.M.R. : Unusual levels of (ADP-ribose), and DNA synthesis in staxia-telangiectasia cells following r-ray irradiation. Nature, $287: 745 \sim 747,1980$.

13) Yount, W.J. : IgG $\mathrm{G}_{2}$ deficiency and ataxia-telangiectasia. N. Engl. J. Med., 306 : 541 543, 1982.

14) Morgan, J.L., Holomb, T.M. and Morrissey, R.W. : Radiation reaction in ataxia-telangiectasia. Amer. J. Dis. Child., $116: 557 \sim 558,1968$.

15) Gotoff, S.P., Amirmokri, E. and Liebner, E.J.: Ataxia-telangiectasia-neoplasia, untoward response to $\mathrm{x}$-irradiation, and tuberous sclerosis. Amer. J. Dis. Child., $114: 617 \sim 625,1967$.

16) Taylor, A.M.R., Metcalf, J.A., Oxford. F.M., et al. : Is chromatid-type damage in ataxia-telangiectasia after irradiation at Go a consequence of defective repair? Nature, $260: 441 \sim$ 443, 1976.

17) Taylor, A.M.R., Rosney, C.M. and Campbell, J.B. : Unusual sensitivity of ataxia-telangiectasia cells to bleomycin. Cancer Res., $39: 1046 \sim$ $1450,1979$.

18) Hecht, F., McCaw, B.K. and Koler, R.D. : Ataxia-telangiectasia-clonal growth of translo. cation lymphocytes. N. Engl. J. Med., 289 : 286 291, 1973.

19) Oxford, J.M., Harnden, D.G., Parrington, J. M., Delhaunty, J.D.A. : Specific chromosome aberrations in ataxia-telangiectasia. J. Med. Genet., $12: 251 \sim 262,1975$.

20）吉村教腺，生田房弘：Ataxia-telangiectasia $の$ 
病理, 神経内科, $5: 537 \sim 552,1976$.

21) Waldmann, T.A. and McIntire, K.R. : Serum alphafetoprotein levels in patients with ataxiatelangiectasia. Lancet, ii : 1112 1115, 1972.

22) Sugimoto, T., Sawada, Y., Tozawa, M., Kidowaki, T., Kusunoki, T. and Yamaguchi, N. : Plasma levels of carcinoembryonic antigen in patients with ataxia-telangiectasia. J. Pediatr., $92: 436 \sim 439,1978$.

23) Jason, J.M. and Gelfand, E.W. : Diagnostic consideration in ataxia-telangiectasia. Arch. Dis. Childh., $54: 682 \sim 686,1979$.

24) Berkel, A.F., Ersoy, F., Epstein, L.B. and Spitler, L.E. : Transfer factor therapy in ata- xia-telangiectasia. Clin. Exp. Immunol., 29 : 376 384, 1977.

25）崎山幸雄 - 松本脩三：Transfer factor. 臨床免疫, $12: 127 \sim 137,1980$.

26) Handzel, Z.T., Dolfin, Z., Levin, S., Altman, Y., Hahn, T., Trainin, N. and Gadot, N. : Effect of thymic humoral factor on cellular immune functions of normal chlidren and of pediatric patients with ataxia-telangiectasia and Dow's syndrome. Pediatr. Res., $13: 803 \sim$ $806,1979$.

27) Buckley, R.H. : Bone marrow and thymus transplantation in ataxia-telangiectasia. Birth Defects., $11: 421 \sim 424,1975$. 